Chapter 9

\title{
Catalytic Hydroprocessing of Liquid Biomass for Biofuels Production
}

\author{
Stella Bezergianni \\ Additional information is available at the end of the chapter \\ http://dx.doi.org/10.5772/52649
}

\section{Introduction}

The depletion of world petroleum reserves and the increased concern on climate change has stimulated the recent interest in biofuels. The most common biofuels are based on energy crops and their products, i.e. vegetable oil for Fatty Acid Methyl Esters (FAME) biodiesel [1] and sugars/starch for bioethanol. However these first generation biofuels and associated production technologies face several considerations related to their economic and social implications regarding energy crops cultivation, by-products disposal, necessity for large investments to ensure competitiveness and the "food versus fuel" debate.

As a result, second generation biofuel technologies have been developed to overcome the limitations of first generation biofuels production [2]. The goal of second generation biofuel processes is to extend biofuel production capacity by incorporating residual biomass while increasing sustainability. This residual biomass consists of the non-food parts of food crops (such as stems, leaves and husks) as well as other non-food crops (such as switch grass, jatropha, miscanthus and cereals that bear little grain). Furthermore the residual biomass potential is further augmented by industrial and municipal organic waste such as skins and pulp from fruit pressing, waste cooking oil etc. One such technology is catalytic hydroprocessing, which is an alternative conversion technology of liquid biomass to biofuels that is lately raising a lot of interest in both the academic and industrial world and is the proposed subject of this chapter.

Catalytic hydroprocessingis a key process in petrochemical industry for over a century enabling heteroatom (sulfur, nitrogen, oxygen, metals) removal, saturation of olefins and aromatics, as well as isomerization and cracking [3]. Due to the numerous applications of catalytic hydroprocessing, there are several catalytic hydroprocessing units in a typical refinery including distillate hydrotreaters and hydrocrackers (see Figure 1). As a result several 
refinery streams are treated with hydrogen in order to improve final product quality including straight-run naphtha, diesel, gas-oils etc. The catalytic hydroprocessing technology is evolving through the new catalytic materials that are being developed. Even though hydroprocessing catalysts development is well established [4], the growing demand of petroleum products and their specifications, which are continuously becoming stricter, have created new horizons in the catalyst development in order to convert heavier and lower quality feedstocks [5]. Furthermore the expansion of the technology to bio-based feedstocks has also broadened the R\&D spam of catalytic hydrotreatment.

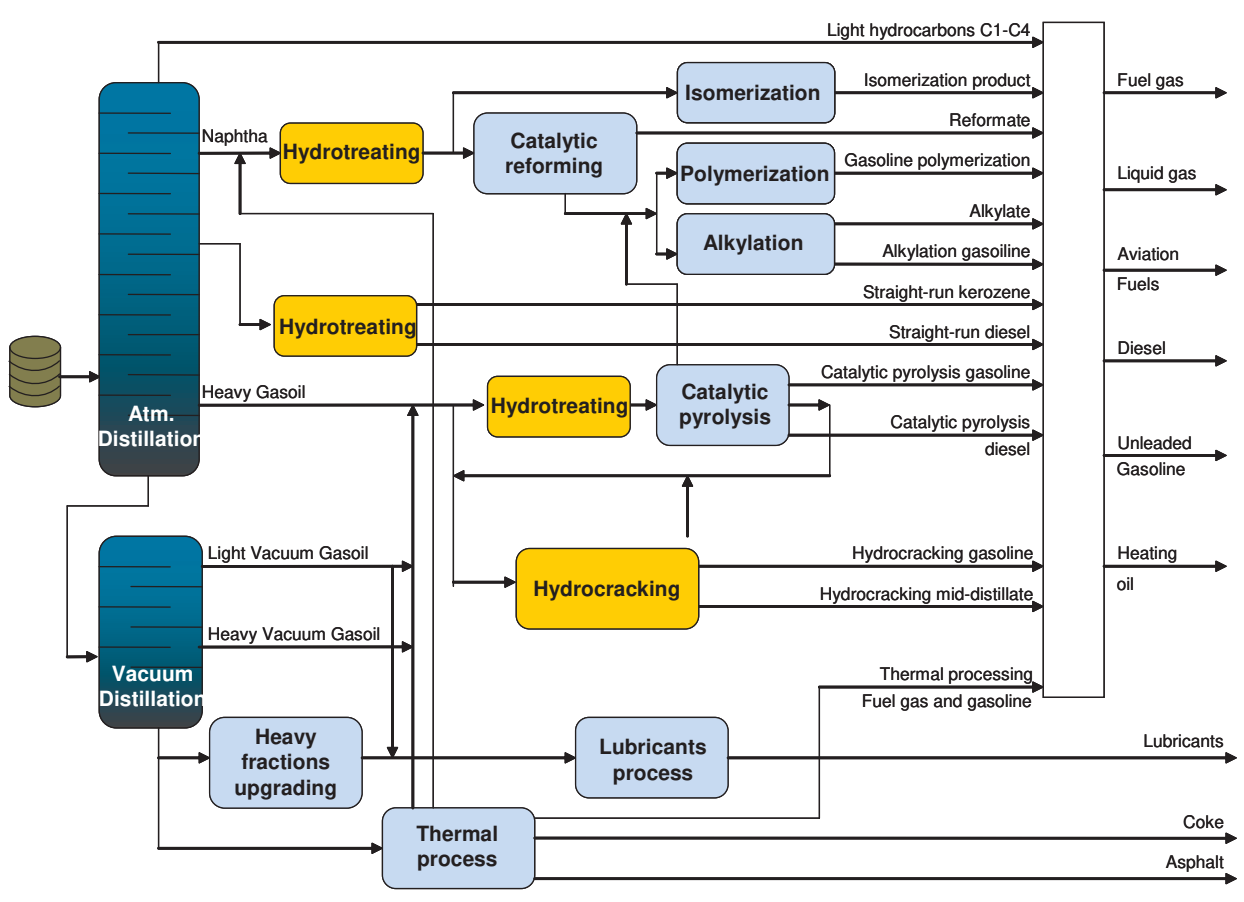

Figure 1. Catalytic hydroprocessing units within a refinery, including distillate hydrotreating and hydrocracking

Catalytic hydroprocessing of liquid biomass is a technology that offers great flexibility to the continuously increasing demands of the biofuels market, as it can convert a wide variety of liquid biomass including raw vegetable oils, waste cooking oils, animal fats as well as algal oils into biofuels with high conversion yields. In general this catalytic process technology allows the conversion of triglycerides and lipids into paraffins and iso-paraffins within the naphtha, kerosene and diesel ranges. The products of this technology have improved characteristics as compared to both their fossil counterparts and the conventional biofuels including high heating value and cetane number, increased oxidation stability, negligible acidity and increased saturation level. Besides the application of this catalytic technology for the production of high quality paraffinic fuels, catalytic hydroprocessing is also an effective 
technology for upgrading intermediate products of solid biomass conversion technologies such as pyrolysis oils and Fischer-Tropsch wax (Figure 2). The growing interest and investments of the petrochemical, automotive and aviation industries to the biomass catalytic hydroprocessing technology shows that this technology will play an important role in the biofuels field in the immediate future.

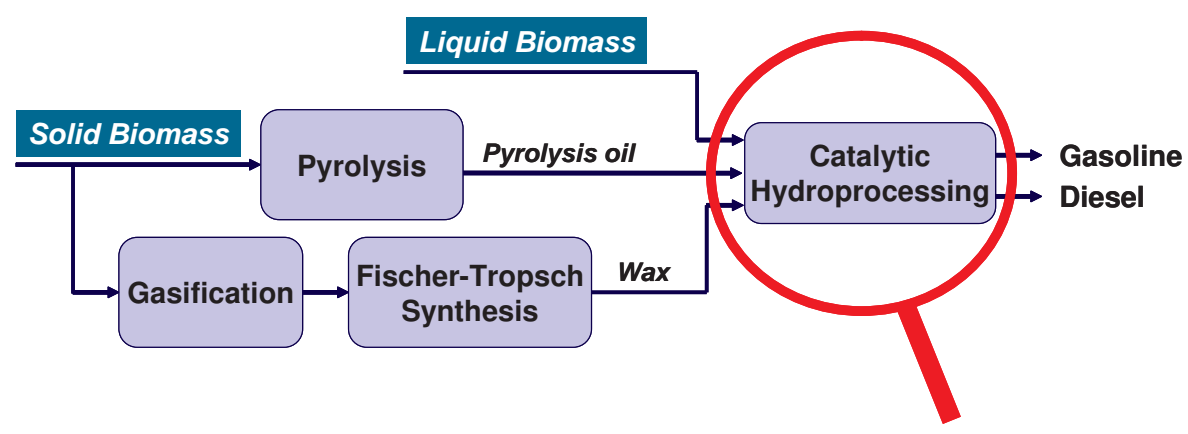

Figure 2. Catalytic hydroprocessing for biomass conversion and upgrading towards fuels production

In the sections that follow, the basic technical characteristics of catalytic hydrotreatment are presented including a description of the process, reactions, operating parameters and feedstock characteristics. Furthermore key applications of catalytic hydroprocessing of liquid biomass are outlined based on different feedstocks including raw vegetable oils, waste cooking oils, pyrolysis oils, Fischer-Tropsch wax and algal oil, and some successful demonstration activities are also presented.

\section{Technical characteristics of catalytichydrotreatment}

The catalytic hydrotreatment of liquid biomass converts the contained triglycerides/lipids into hydrocarbons at high temperatures and pressures over catalytic material under excess hydrogen atmosphere. The catalytic hydrotreatment of liquid biomass process is quite similar to the typical process applied to petroleum streams, as shown in Figure 3. A typical catalytic hydrotreatment unit consists of four basic sections: a) feed preparation, b) reaction, c) product separation and d) fractionation.

In the feed preparation section the liquid biomass feedstock is mixed with the high pressure hydrogen (mainly from gas recycle with some additional fresh make-up hydrogen) and is preheated before it enters the reactor section. The reactor section consists normally of two hydrotreating reactors, a first guard mild hydrotreating reactor and a second one where the main hydrotreating reactions take place. Each reactor contains two or more catalytic beds in order to maintain constant temperature profile throughout the reactor length. Within the reactor section all associated reactions take place, which will be presented in more detail at a later paragraph. 
The reactor product then enters the separator section where, after it is cooled down, it enters the high pressure separator (HPS) flash drum in which the largest portion of the gas and liquid product molecules are separated. The gas product of the HPS includes the excess hydrogen that has not reacted within the reactor section as well as the side products of the reactions including $\mathrm{CO}, \mathrm{CO}_{2}, \mathrm{H}_{2} \mathrm{~S}, \mathrm{NH}_{3}$ and $\mathrm{H}_{2} \mathrm{O}$. The liquid product of the HPS is lead to a second flash drum, the low pressure separator (LPS), for removing any residual gas contained in the liquid product, and subsequently is fed to a fractionator section. The fractionator section provides the final product separation into the different boiling point fractions that yield the desired products including off-gas, naphtha, kerosene and diesel. The heaviest molecules return from the bottom of the fractionator into the reactor section as a liquid recycle stream.

In order to improve the overall efficiency, a liquid recycle stream is also incorporated, which in essence consists of the heavy molecules that were not converted. The gas product from the HPS and LPS, after being treated to remove the excess $\mathrm{NH}_{3}, \mathrm{H}_{2} \mathrm{~S}, \mathrm{CO}$ and $\mathrm{CO}_{2}$, is compressed and fed back to the reactor section as a gas recycle stream in order to maintain a high pressure hydrogen atmosphere within the reactor section.

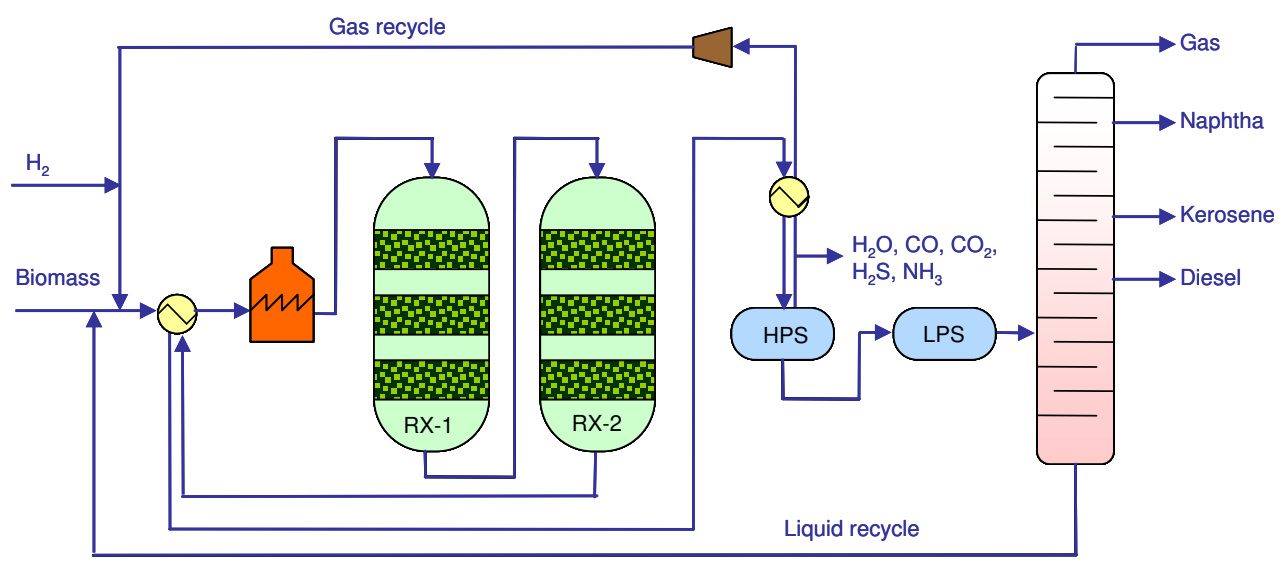

Figure 3. A typical process diagram of catalytic hydrotreatment of liquid biomass

\subsection{Reaction mechanisms}

Several types of reactions take place during catalytic hydrotreatment of liquid biomass, based on the type of biomass processed, operating conditions and catalyst employed. The types of reactions that liquid biomass undergoes during catalytic hydroprocessing include: a) cracking, b) saturation, c) heteroatom removal and d) isomerization, which are described in more detail in the following section. 


\subsubsection{Cracking}

As the molecules included in the various types of liquid biomass can be relatively large and complicated, cracking reactions are desired to convert them into molecules of the size and boiling point range of conventional fuels, mainly gasoline, kerosene and diesel. A characteristic reaction that occurs during catalytic hydrotreating of oils / fats is the cracking of triglycerides into its consisting fatty acids (carboxylic acids) and propane as shown in Scheme 1 [5][6]. This reaction is critical as it converts the initial large triglycerides molecules of boiling point over $600^{\circ} \mathrm{C}$ into mid-distillate range molecules (naphtha, kerosene and diesel).

Other cracking reactions may take place however such as those described in Schemes 2 and 3 , depending on the type of molecules present in the feedstock. For example Scheme 2 is a cracking reaction which may occur during catalytic hydrotreatment of pyrolysis oil which includes polyaromatic and aromatic compounds. Alternatively Scheme 3 may follow deoxygenation of carboxylic acids on the produced long chain paraffinic molecules, leading to smaller chain paraffins, during the upgrading of Fischer-Tropsch wax.<smiles>[R]C(=O)OCC(COC([R])=O)OC(=O)[PH2+]CC[R]CC(=O)O[CH-]CCC</smiles>

Triglyceride carboxylic acid propane

Scheme 1.<smiles>[R]Cc1ccccc1</smiles>

Scheme 2.

$$
\mathrm{R}-\mathrm{R}^{\prime}+\mathrm{H}_{2} \longrightarrow \mathrm{R}-\mathrm{H}+\mathrm{R}^{\prime}-\mathrm{H}
$$

Scheme 3.

\subsubsection{Saturation}

Saturation reactions are strongly associated with catalytic hydrotreating as the introduction of excess hydrogen allows the breakage of double C-C bonds and their conversion to single 
bonds, as shown in the following reactions. In particular the saturation of unsaturated carboxylic acids into saturated ones depicted in Scheme 4, is a key reaction occurring in lipid feedstocks. Furthermore other saturation reactions lead to the formation of naphthenes by converting unsaturated cyclic compounds and aromatic compounds as in Scheme 5 and 6, which are likely to occur during upgrading of pyrolysis oils.

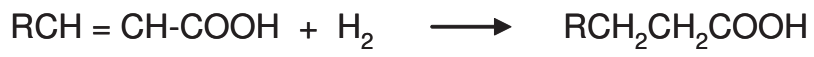

Scheme 4.

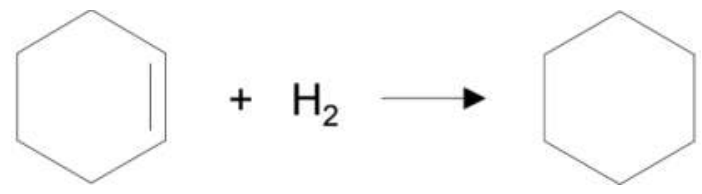

Scheme 5 .

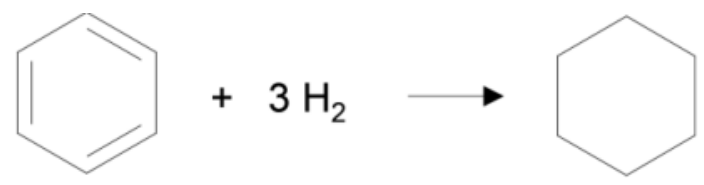

Scheme 6.

As a result of this reaction the produced saturated molecules are less active and less prone to polymerization and oxidation reactions, mitigating the sediment formation and corrosion phenomena appearing in engines.

\subsubsection{Heteroatom removal}

Heteroatoms are atoms other than carbon $(\mathrm{C})$ and hydrogen $(\mathrm{H})$ and are often encountered into bio- and fossil- based feedstocks. They include sulfur (S), nitrogen $(\mathrm{N})$ and in the case of bio-based feedstocks oxygen $(\mathrm{O})$. In particular oxygen removal is of outmost importance as the presence of oxygen reduces oxidation stability (due to carboxylic and carbonylic double bonds), increases acidity and corrosivity (due to the presence of water) and even reduces the heating value of the final biofuels. The main deoxygenation reactions that take place include deoxygenation, decarbonylation and decarboxylation presented in Schemes 7, 8 and 9 respectively [7]. The main products of deoxygenation reactions include n-paraffins, while $\mathrm{H}_{2} \mathrm{O}, \mathrm{CO}_{2}$ and $\mathrm{CO}$ are also produced, but can be removed with the excess hydrogen within the flash drums of the product separation section. It should be noted however that these particular reactions give the paraffinic nature of the produced biofuels, and for this reason the hydrotreated products are often referred to as paraffinic fuels (e.g. paraffinic jet, paraffinic diesel etc) 


$$
\mathrm{R}-\mathrm{CH}_{2} \mathrm{COOH}+3 \cdot \mathrm{H}_{2} \longrightarrow \mathrm{R}-\mathrm{CH}_{2} \mathrm{CH}_{3}+2 \cdot \mathrm{H}_{2} \mathrm{O}
$$

Scheme 7.

$$
\mathrm{R}-\mathrm{CH}_{2} \mathrm{COOH}+\mathrm{H}_{2} \longrightarrow \mathrm{R}-\mathrm{CH}_{3}+\mathrm{CO}+\mathrm{H}_{2} \mathrm{O}
$$

Scheme 8 .

$$
\mathrm{R}-\mathrm{CH}_{2} \mathrm{COOH}+\mathrm{H}_{2} \longrightarrow \mathrm{R}-\mathrm{CH}_{3}+\mathrm{CO}_{2}
$$

\section{Scheme 9.}

The other heteroatoms, i.e. $\mathrm{S}$ and $\mathrm{N}$ are removed according to the classic heteroatom removal mechanisms of the fossil fuels in the form of gaseous $\mathrm{H}_{2} \mathrm{~S}$ and $\mathrm{NH}_{3}$ respectively.

\subsubsection{Isomerization}

The straight chain paraffinic molecules resulting from the aforementioned reactions, even though they offer increased cetane number, heating value and oxidation stability in the biofuels which contain them, they also degrade their cold flow properties. In order to improve the cold flow properties, isomerization reactions are also required, which normally take place during a second step/reactor as they require a different catalyst. Some examples of isomerization reactions are given in Schemes 10 and 11.<smiles>[R]CCCCC(C)C</smiles>

Scheme 10.

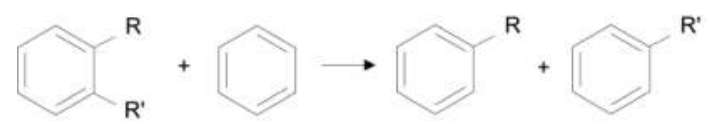

Scheme 11.

\subsection{Hydroprocessing catalysts}

Catalytic hydroprocessing of liquid biomass is a technology currently under developed and there is a lot of room for optimization. For example there are not many commercial catalysts specifically designed and developed for such applications, while conventional commercial catalysts, employed for catalytic hydroprocessing of refinery streams, are used instead. Common 
hydrotreating catalysts employed contain active metals on alumina substrate with increased surface area. The most known commercial catalysts employ Cobalt and Molybdenum (CoMo) or Nikel and Molybdenum (NiMo) in alumina substrate $\left(\mathrm{Al}_{2} \mathrm{O}_{3}\right)$ as shown in Figure 4 .

(a)

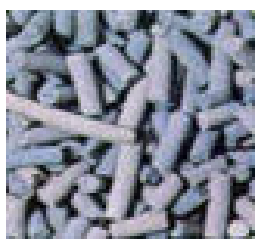

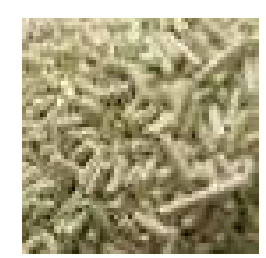

(b)

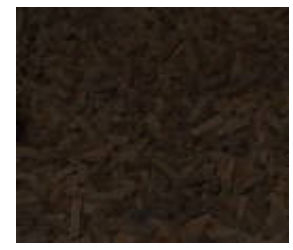

Figure 4. Typical hydrotreating catalysts (a) before use and (b) after use

Hydrotreating catalysts are dual action catalytic material, triggering both hydrogenation and cracking/isomerization reactions. On one hand hydrogenation takes place on the active metals (Mo, Ni, Co, Pd, Pt) which catalyze the feedstock molecules rendering them more active when subject to cracking and heteroatom removal, while limiting coke formation on the catalyst. Furthermore hydrogenation supports cracking by forming an active olefinic intermediate molecule via dehydrogenation. On the other hand both cracking and isomerization reactions take place in acidic environment such as amorphous oxides $\left(\mathrm{SiO}_{2}-\mathrm{Al}_{2} \mathrm{O}_{3}\right)$ or crystalline zeolites (mainly z-zeolites) or mixtures of zeolites with amorphous oxides.

During the first contact of the feedstock molecules with the catalyst, a temperature increase is likely to develop due to the exothermic reactions that occur. However, during the continuous utilization of the catalyst and coke deposition, the catalyst activity eventually reduces from $1 / 3$ to $1 / 2$ of its initial one. The catalyst deactivation rate mainly depends on temperature and hydrogen partial pressure. Increased temperatures accelerate catalyst deactivation while high hydrogen partial pressure tends to mitigate catalyst deactivation rate. Most of the catalyst activity can be recovered by catalyst regeneration.

The selection of a suitable hydroprocessing catalyst is a critical step defining the hydroprocessing product yield and quality as well as the operating cycle time of the process in petroleum industry [5]. However the hydrotreating catalyst selection for biomass applications is particularly crucial and challenging for two reasons: a) catalyst activity varies significantly, as commercial catalysts are designed for different feedstocks, i.e. feedstocks with high sulfur concentration, heavy feedstocks (containing large molecules), feedstocks with high oxygen concentration etc, and b) there are currently no commercial hydroprocessing catalysts available for lipid feedstocks and other intermediate products of biomass conversion processes (e.g. pyrolysis biooil), and thus commercial hydrotreating catalysts need to be explored and evaluated as different catalyst have different yields (Figure 5) and different degradation rate [8]. Nevertheless, significant efforts have been directed to- 
wards developing special hydrotreating catalysts for converting/upgrading liquid biomass to biofuels [9-12].

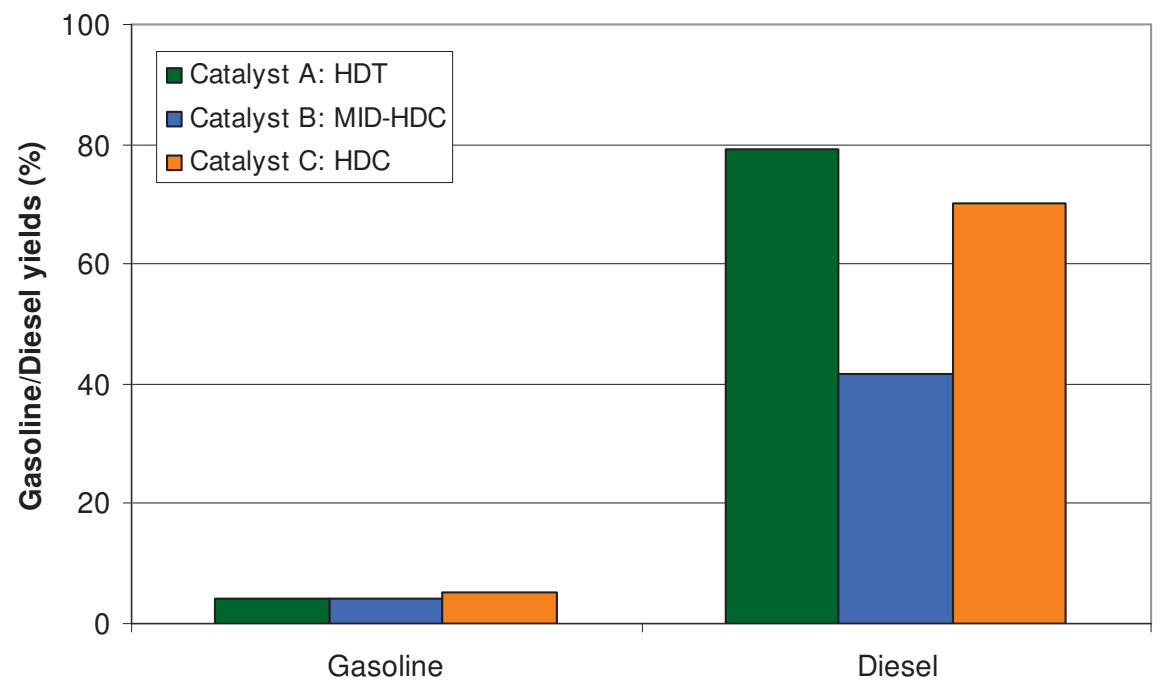

Figure 5. Catalyst comparison based on gasoline and diesel yields for WCO hydrotreating [8]. (Reprinted from Fuel, 93, S. Bezergianni, A. Kalogianni, A. Dimitriadis, Catalyst evaluation for waste cooking oil hydroprocessing, 638-641, 2012, with permission from Elsevier).

\subsection{Operating parameters}

As it was mentioned earlier, the choice of catalyst and operating parameters affect the reactions that take place within the hydroprocessing reactor. The key operating parameters of hydroprocessing include the reactor temperature, hydrogen partial pressure, liquid hourly space velocity and hydrogen feed-rate.

\subsubsection{Temperature}

Most catalytic hydrotreating and hydrocracking reactors operate between $290-450^{\circ} \mathrm{C}$. The temperature range is selected according the type of catalyst and feedstock type to be processed. In the first stages of the catalyst life (after its loading in the reactor) the temperature is normally kept low as the catalyst activity is already very high. However as time progresses and the catalyst deactivates and cokes, the temperature is gradually increased to overcome the loss of catalyst activity and to maintain the desired product yield and quality.

\subsubsection{Hydrogen partial pressure}

Hydrogen partial pressure affects significantly the hydrotreating reactions as well as the catalyst deactivation. The catalyst deactivation rate is inverse proportional to the hydrogen 
partial pressure and to hydrogen feed-rate. However high hydrogen partial pressures correspond to high operational costs, which rise even higher for high olefinic feedstocks that exhibit higher hydrogen consumption due to the saturation reactions. Therefore hydrogen partial pressure should be balanced with the catalyst activity and catalyst life expectancy in order to optimize the overall process.

\subsubsection{Liquid hourly space velocity}

Liquid hourly space velocity (LHSV) is defined as the ratio of the liquid mass feed-rate $(\mathrm{gr} / \mathrm{h})$ over the catalyst mass (gr) and as a result is expressed in $\mathrm{hr}^{-1}$. In fact the inverse of LHSV is proportional to the residence time of the liquid feed in the reactor. In essence the higher the liquid hourly space velocity, the less time is available for the contact of the feed molecules of the reaction mixture with the catalyst, thus the less the conversion. However, maintaining large LHSV imposes a faster degradation of the catalyst therefore in industrial applications the LHSV is maintained in as high values as it is practically possible.

\subsubsection{Hydrogen feed-rate}

The hydrogen feed-rate is another important parameter as it also defines hydrogen partial pressure depending on the hydrogen consumption of each application. It actually favours both heteroatom removal and saturation reaction rates. However, as hydrogen cost defines the overall unit operating cost, hydrogen feed-rate is normally optimized depending on the system requirements. Furthermore the use of renewable energy sources for hydrogen production is also envisioned as a potential cost improvement option.

\section{Feed sand products}

Even though liquid biomass is currently being exploited as a renewable feedstock for fuels production, its characteristics are far beyond suitable for its use as fuel. More specifically liquid biomass, just as other types of biomass, has a small $\mathrm{H} / \mathrm{C}$ ratio and high oxygen content, lowering its heating value and increasing $\mathrm{CO}$ and $\mathrm{CO}_{2}$ emissions during its combustion. Moreover liquid biomass contains water, which can cause corrosion in the downstream processing units if it's not completely removed, or even in the engine parts where its final products are utilized. In addition to the above, liquid biomass has an increased concentration in oxygenated compounds, mainly acids, aldehydes, ketones etc, which not only reduce the heating value, but also decrease the oxidation stability and increase the acidity of the produced biofuels. For all the aforementioned reasons it is imperative that liquid biomass should be upgraded and specifically that its $\mathrm{H} / \mathrm{C}$ should be increased while the water and oxygen removed.

The effectiveness of catalytic hydroprocessing towards improving these problematic characteristics of liquid biomass is presented in Table 1, where the $\mathrm{H} / \mathrm{C}$ ratio, the oxygen content and density before and after catalytic hydrotreatment of basic liquid biomass types are given. The $\mathrm{H} / \mathrm{C}$ ratio exhibits a significant increase that exceeds $50 \%$ in all cases. This is due to the substitution of the heteroatoms by hydrogen atoms as well as in the saturation of 
double bonds that enriches the H/C analogy. The oxygen content (including the oxygen contained in the water) from over $15 \%$ wt can be decreased down to $5 \mathrm{wppm}$. Actually the deep deoxygenation achieved via catalytic hydrotreatment is the most significant contribution of this biomass conversion technology, as it improves significantly the oxidation stability of the final biofuels. Furthermore significant improvement is also observed in the biomass density, which is never below $0.9 \mathrm{~kg} / \mathrm{l}$ while after hydrotreatment it reduces to values less than $0.8 \mathrm{~kg} / \mathrm{l}$

\begin{tabular}{ccc}
\hline & $\begin{array}{c}\text { Liquid biomass } \\
\text { (unprocessed) }\end{array}$ & $\begin{array}{c}\text { Hydrotreated liquid biomass } \\
\text { and produced biofuels }\end{array}$ \\
\hline H/C ratio & $0.08-0.1$ & $0.13-0.18$ \\
\hline Oxygen content (\%wt) & $15-40$ & $10^{-4}-3$ \\
\hline Density $(\mathrm{kg} / \mathbf{l})$ & $0.9-1.05$ & $0.75-0.8$ \\
\hline
\end{tabular}

Table 1. Effect of catalytic hydrotreatment on the liquid biomass characteristics

Catalytic hydroprocessing has been proven as the most efficient technology for the upgrading of liquid biomass as it achieves to increase the $\mathrm{H} / \mathrm{C}$ ratio and to remove oxygen and water. However the effectiveness of this technology is also shown in other parameters. For example the distillation curve of raw liquid biomass shows that over $90 \%$ of its molecules have boiling points exceeding $600^{\circ} \mathrm{C}$ and only $5 \%$ are within diesel range $\left(220-360^{\circ} \mathrm{C}\right)$, while after catalytic hydrotreatment upgrading most of $90 \%$ of the product molecules are within diesel range [13].

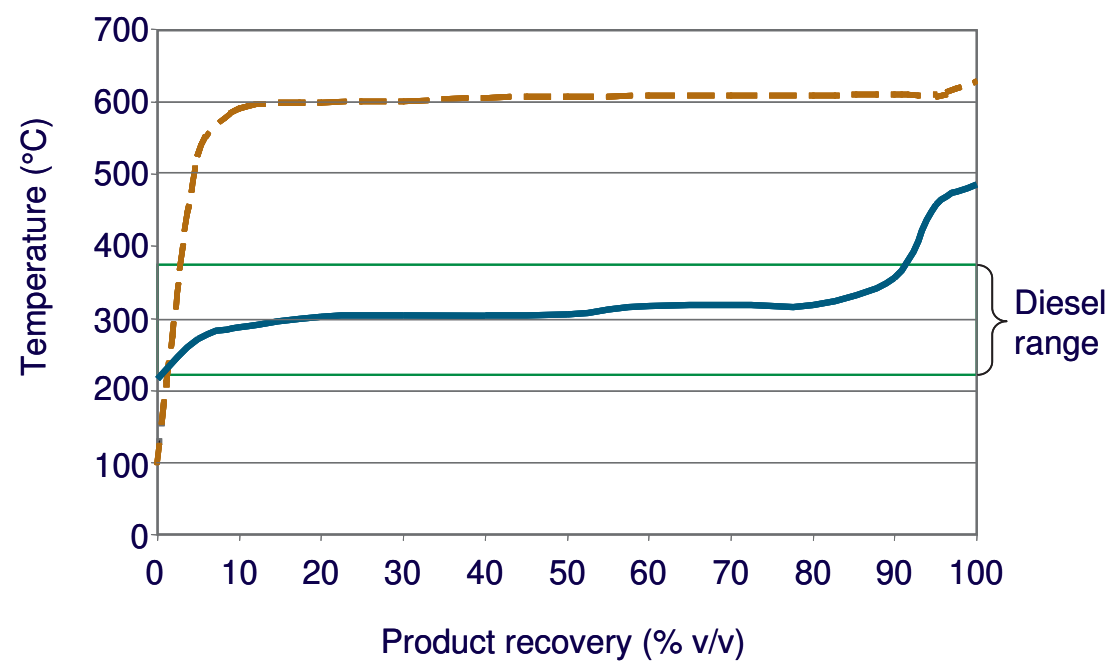

Figure 6. Distillation curves of untreated WCO (dashed) and catalytically hydrotreated WCO (solid) 
In the following sections the basic types of liquid biomass and their corresponding products via catalytic hydrotreatment are presented.

\subsection{Raw vegetable oils conversion to paraffinic biofuels}

Vegetable oils are the main feedstock for the production of first generation biofuels, which can offer several $\mathrm{CO}_{2}$ benefits and limit the consumption of fossil fuels. Raw vegetable oils consist of fatty acid triglycerides, the consistency of which depends on their origin (i.e. plant type) as shown in Table 2. Their production, however, is competing for the cultivated areas that were originally dedicated for the production of food and feed crops. As a result the production and utilization of vegetable oils for biofuels production has instigated the "food vs. fuel" debate. For this reason traditional energy crops (soy, cotton, etc) with low oil yield per hectare are being substituted by new energy crops (eg. jatropha, palm, castor etc).

\begin{tabular}{|c|c|c|c|c|c|c|c|c|c|c|c|c|c|}
\hline & & C8:0 & C10:0 & C12:0 & C14:0 & C16:0 & C16:1 & C18:0 & C18:1 & C18:2 & C18:3 & $\begin{array}{l}\text { C20:0/ } \\
\text { C22:0 }\end{array}$ & $\begin{array}{l}\text { C20:1/ } \\
\text { C22:1 }\end{array}$ \\
\hline \multirow{4}{*}{ 구 } & Rapeseed oil & 0.0 & 0.0 & 0.0 & 0.0 & 3.5 & 1.0 & 1.5 & 12.5 & 15.0 & 7.5 & 9.0 & 50.0 \\
\hline & Soybean oil & 0.0 & 0.0 & 0.0 & 0.3 & 8.2 & 0.5 & 4.5 & 25.0 & 49.0 & 5.0 & 7.5 & 0.0 \\
\hline & Sunflower oil & 0.0 & 0.0 & 0.0 & 0.0 & 6.0 & 0.0 & 4.2 & 18.8 & 69.3 & 0.3 & 1.4 & 0.0 \\
\hline & Corn oil & 0.0 & 0.0 & 0.0 & 1.0 & 9.0 & 1.5 & 2.5 & 40.0 & 45.0 & 0.0 & 0.0 & 1.0 \\
\hline \multirow{4}{*}{ 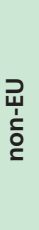 } & Palm oil & 0.0 & 0.0 & 0.0 & 3.5 & 39.5 & 0.0 & 3.5 & 47.0 & 6.5 & 0.0 & 0.0 & 0.0 \\
\hline & Peanut oil & 0.0 & 0.0 & 0.0 & 0.5 & 8.0 & 1.5 & 3.5 & 51.5 & 27.5 & 0.0 & 7.5 & 0.0 \\
\hline & Canola oil & 0.0 & 0.0 & 0.1 & 0.1 & 4.7 & 0.1 & 1.6 & 65.9 & 21.2 & 5.2 & 1.2 & 0.0 \\
\hline & Castor oil & 0.0 & 0.1 & 0.2 & 10.6 & 1.4 & 9.5 & 29.7 & 29.7 & 41.3 & 3.3 & 3.8 & 0.0 \\
\hline
\end{tabular}

Table 2. Fatty acid composition of most common vegetable oils [14][15]

Catalytic hydrotreatment was explored for conversion of vegetable oils in the early 90 's. The investigation of the hydrogenolysis of various vegetable oils such as maracuja, buritimtucha and babassu oils over a $\mathrm{Ni}-\mathrm{Mo} / \gamma-\mathrm{Al}_{2} \mathrm{O}_{3}$ catalyst as well as the effect of temperature and pressure on its effectiveness was firstly investigated [16][17]. The reaction products included a gas product rich in the excess hydrogen, carbon monoxide, carbon dioxide and light hydrocarbons as well as a liquid organic product of paraffinic nature. In more detail these studies showed the conversion of triglycerides into carboxyl oxides and then to high quality hydrocarbons via decarboxylation and decarbonylation reactions. Rapeseed oil hydroprocessing was also studied in lab-scale reactor for temperatures $310^{\circ}$ and $360^{\circ} \mathrm{C}$ and hydrogen pressures of 7 and $15 \mathrm{MPa}$ using three different Ni-Mo/alumina catalysts [18]. These products contained mostly n-heptadecane and n-octadecane accompanied by low concentrations of other n-alkanes and i-alkanes [19]. 


\subsection{Waste cooking oils conversion to paraffinic biofuels}

Even though vegetable oils are the main feedstock for the production of first generation biofuels, soon their production has troubled the public opinion due to their abated sustainability and to their association with the food vs. fuel debate. As a result the technology has shifted towards the exploitation of both solid and liquid residual biomass. Waste Cooking Oils (WCOs) is a type of residual biomass resulting from frying with typical vegetable frying oils (e.g. soybean-oil, corn-oil, olive-oil, sesame-oil etc). WCOs have particular problems regarding their disposal. In particular grease may result in coating of pipelines within the residential sewage system and is one of the most common causes of clogs and sewage spills. Furthermore, in the cases that sewage leaks into the environment, WCOs can cause human and environmental health problems because of the pathogens contained. It has been estimated that by disposing 1 lit of WCO, over 1,000,000 of liters of water can be contaminated, which is estimated as the average demand of a single person for 14 years.

Catalytic hydroprocessing of WCO was studied as an alternative approach of producing $2^{\text {nd }}$ generation biofuels [20-24]. Initially catalytic hydrocracking was investigated over commercial hydrocracking catalysts leading not only to biodiesel but also to lighter products such as biogasoline [20], employing a continuous-flow catalytic hydroprocessing pilot-plant with a fixed-bed reactor. During this study several parameters were considered including hydrocracking temperature $\left(350-390^{\circ} \mathrm{C}\right)$ and liquid hourly space velocity or LHSV $\left(0.5-2.5 \mathrm{hr}^{-1}\right)$ under high pressure (140 bar), revealing that the conversion is favoured by high reaction temperature and low LHSV. Lower and medium temperatures, however, were more suitable for biodiesel production while higher temperatures offered better selectivity for biogasoline production. Furthermore, heteroatom removal (S, N and particularly O) was increased while saturation of double bonds was decreased with increasing hydrocracking temperature, indicating the necessity of a pre-treatment step.

However catalytic hydrotreatment was later examined in more detail as a more promising technology particularly for paraffinic biodiesel production (Figure 1). The same team has studied the effect of temperature $\left(330-398^{\circ} \mathrm{C}\right)$ on the product yields and heteroatom removal [21]. The study was conducted in the same pilot plant utilizing a commercial $\mathrm{NiMo} / \mathrm{Al}_{2} \mathrm{O}_{3}$ hydrotreating catalyst over lower pressure ( 80 bar). According to this study, the hydrotreating temperature is the key operating parameter which defines the catalyst effectiveness and life. In fact lower temperatures $\left(330^{\circ} \mathrm{C}\right)$ favour diesel production and selectivity. Sulfur and nitrogen removal were equally effective at all temperatures, while oxygen removal and saturation of double bonds were favoured by hydrotreating temperature. The same team also studied the effect of the other three operating parameters i.e. pressure, LHSV and $\mathrm{H}_{2} / \mathrm{WCO}$ ratio [22]. Moreover they also studied the hydrocarbon content of the products [23] qualitatively via two-dimensional chromatography and quantitatively via Gas Chromatography with Flame Ionization Detector (GC-FID), which indicated the presence of C15-C18 paraffins. Interestingly this study showed that as hydrotreating temperature increases, the content of normal paraffins decreases while of iso-paraffins increases, revealing that isomerization reactions are favoured by temperature. 


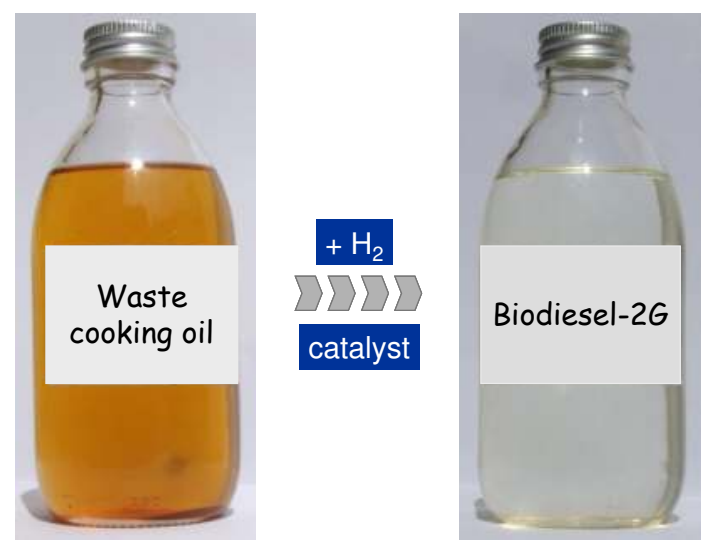

Figure 7. Catalytic hydrotreatment of WCO to $2^{\text {nd }}$ generation biodiesel

The total liquid product of WCO catalytic hydrotreatment was further investigated in terms of its percentage that contains paraffins within the diesel boiling point range $\left(220-360^{\circ} \mathrm{C}\right)$ [24]. The properties of WCO, hydrotreated WCO (total liquid product) and the diesel fraction of the hydrotreated WCO are presented in Table 3. Based on this study the overall yield of the WCO catalytic hydrotreatment technology was estimated over $92 \% \mathrm{v} / \mathrm{v}$. The properties of the new $2^{\text {nd }}$ generation paraffinic diesel product indicated a high-quality diesel with high heating value $(49 \mathrm{MJ} / \mathrm{kg}$ ) and high cetane index (77) which is double of the one of fossil diesel. An additional advantage of the new biodiesel is its oxidation stability (exceeding 22hrs) and negligible acidity, rendering it as a safe biofuel, suitable for use in all engines. The properties and potential of the new biodiesel were further studied [25], for evaluating different fractions of the total liquid product and their suitability as an alternative diesel fuel.

\begin{tabular}{ccccc}
\hline & & WCO & Hydrotreated WCO & Final biodiesel \\
\hline Density & $\mathrm{gr} / \mathrm{cm}^{3}$ & 0.896 & 0.7562 & 0.7869 \\
\hline $\mathbf{C}$ & $\mathrm{wt} \%$ & 76.74 & 84.59 & 86.67 \\
\hline $\mathbf{H}$ & $\mathrm{wt} \%$ & 11.61 & 15.02 & 14.74 \\
\hline $\mathbf{S}$ & $\mathrm{wppm}$ & 38 & 11.80 & 1.54 \\
\hline $\mathbf{N}$ & $\mathrm{wppm}$ & 47.42 & 0.77 & 1.37 \\
\hline $\mathbf{0}$ & $\mathrm{wt} \%$ & 14.57 & 0.38 & 0 \\
\hline Recovery $\mathbf{0} \%$ & ${ }^{\circ} \mathrm{C}$ & 431.6 & 195.6 & 234.1 \\
\hline Recovery $\mathbf{1 0} \%$ & ${ }^{\circ} \mathrm{C}$ & 556.4 & 287.4 & 296.1 \\
\hline Recovery $\mathbf{3 0} \%$ & ${ }^{\circ} \mathrm{C}$ & 599 & 304.0 & 298.3 \\
\hline Recovery $\mathbf{5 0} \%$ & ${ }^{\circ} \mathrm{C}$ & 603.2 & 314.4 & 300 \\
\hline Recovery $\mathbf{7 0} \%$ & ${ }^{\circ} \mathrm{C}$ & 609 & 319.0 & 298.3 \\
\hline Recovery $\mathbf{9 0} \%$ & ${ }^{\circ} \mathrm{C}$ & 612.4 & 320.4 & 306.2 \\
\hline Recovery $\mathbf{1 0 0} \%$ & ${ }^{\circ} \mathrm{C}$ & 727.2 & 475.4 & \\
\hline
\end{tabular}

Table 3. Basic properties of waste cooking oil, hydrotreated waste cooking oil and final biodiesel 


\subsection{Pyrolysis oil upgrading}

Pyrolysis oil is the product of fast pyrolysis of biomass, a process that allows the decomposition of large organic compounds of biomass such as lignin at medium temperatures in the presence of oxygen. Pyrolysis, that is in essence thermal cracking of biomass, is a well established process for producing bio-oil, the quality of which however is far too poor for direct use as transportation fuel. The product yields and chemical composition of pyrolysis oils depend on the biomass type and size as well as on the operating parameters of the fast pyrolysis. However, a major distinction between pyrolysis oils is based on whether catalyst is employed for the fast pyrolysis reactions or not. Non-catalytic pyrolysis oils have a higher water content than catalytic pyrolysis oils, rendering the downstream upgrading process a more challenging one for the case of the non-catalytic pyrolysis oils.

Untreated pyrolysis oil is a dark brown, free-flowing liquid with about $20-30 \%$ water that cannot be easily separated. It is a complex mixture of oxygenated compounds including water solubles (acids, alcohols, ethers) and water insolubles (n-hexane, di-chloor-methane), which is unstable in long-term storage and is not miscible with conventional hydrocarbonbased fuels. It should be noted that due to its nature pyrolysis oil can be employed for the production of a wide range of chemicals and solvents. However, if pyrolysis oil is to be used as a fuel for heating or transportation, it requires upgrading leading to its stabilization and conversion to a conventional hydrocarbon fuel by removing the oxygen through catalytic hydrotreating. For this reason, a lot of research effort is focused on catalytic hydrotreating of pyrolysis oil, as it is a process enabling oxygen removal and conversion of the highly corrosive oxygen compounds into aromatic and paraffinic hydrocarbons.

For non-catalytic pyrolysis oils, the catalytic hydrotreating upgrading process involves contact of pyrolysis oil molecules with hydrogen under pressure and at moderate temperatures $\left(<400^{\circ} \mathrm{C}\right)$ over fixed bed catalytic reactors. Single-stage hydrotreating has proved to be difficult, producing a heavy, tar-like product. Dual-stage processing, where mild hydrotreating is followed by more severe hydrotreating has been found to overcome the reactivity of the bio-oil. Overall, the pyrolysis oil is almost completely deoxygenated by a combination of hydro deoxygenation and decarboxylation. In fact less than $2 \%$ oxygen remains in the treated, stable oil, while water and off-gas are also produced as byproducts. The water phase contains some dissolved organics, while the off-gas contains light hydrocarbons, excess hydrogen, and carbon dioxide. Once the stabilized oil is produced it can be further processed into conventional fuels or sent to a refinery. Table 1 shows the properties of some common catalytic pyrolysis oils according to literature.

Catalytic pyrolysis oils have been reported to getting upgraded via single step hydroprocessing, most of the times utilizing conventional CoMo and NiMo catalysts. During the single step hydroprocessing, the catalytic pyrolysis oil feedstock is pumped to high pressure, then mixed with compressed hydrogen and enters the hydroprocessing reactor. In Table 5 the typical operating parameters for single stage hydroprocessing and associated deoxygenation achievements are given according to literature [29;33-38]. 


\begin{tabular}{|c|c|c|c|c|c|c|c|c|}
\hline & & \multicolumn{7}{|c|}{ Types of Pyrolysis Biooils } \\
\hline Properties & Test Methods & {$[26]$} & [27] & [28] & [29] & [30] & [31] & [32] \\
\hline $\mathrm{H}_{2} \mathrm{O}$ content (\%wt) & KarlFisher & 20 & 23.9 & 30 & $20-30$ & 29.85 & & \\
\hline $\mathrm{pH}$ & pHmeter & 2.2 & & 2.5 & $2 \sim 3$ & & 2.5 & \\
\hline Density $15 \mathrm{C}(\mathrm{Kg} / \mathrm{L})$ & ASTM D4052 & 1.207 & & 1.2 & $1.15-1.2$ & 1.192 & 1.2 & 1.19 \\
\hline $\mathrm{HHV}(\mathrm{MJ} / \mathrm{Kg})$ & DIN51900 & 17.57 & & & & & & \\
\hline LHV (MJ/Kg) & DIN51900 & 15.83 & & & & & & \\
\hline Solids Content (\%wt) & Insolubles in Ethanol & 0.06 & & & & & & \\
\hline Ash content (\%wt) & ASTM D482 & 0.0034 & $<0.1$ & & 0.1 & 0.15 & $0-0.2$ & \\
\hline Pour point & ASTM D97 & -30 & & & & -30 & & \\
\hline Flash point & ASTM D93 & 48 & & $40-65$ & $40-65$ & 51 & & \\
\hline Viscosity (cP) @ 40C & & & & 40 & $40-100$ & & $40-100$ & $43-1510$ \\
\hline Viscosity $\left.20^{\circ} \mathrm{C} 9 \mathrm{~mm} 2 / \mathrm{s}\right)$ & ASTM D445 & 47.18 & & & & & & \\
\hline Viscosity $50^{\circ} \mathrm{C}(\mathrm{mm} 2 / \mathrm{s})$ & ASTM D445 & 9.726 & & & & & & \\
\hline Carbon (\%wt) & ASTM D5291 & 42.64 & 40.1 & 51.1 & $\sim 52$ & 39.17 & $54-58$ & $39.4-46.7$ \\
\hline Hydrogen (wt\%) & ASTM D5291 & 5.83 & 7.6 & 7.3 & $\sim 6.4$ & 8.04 & $5.5-7$ & $7.2-7.9$ \\
\hline Nitrogen (wt\%) & ASTM D5291 & 0.1 & 0.1 & & $\sim 0.2$ & 0.05 & $0-0.2$ & 0.2 \\
\hline Sulphur (\%wt) & ASTM & 0.01 & & & & & & 0.032 \\
\hline Clorine (\%wt) & ASTM & 0.012 & & & & & & \\
\hline AlkaliMetals (\%wt) & ICP & $<0.003$ & & & & & & \\
\hline Oxygen (wt\%) & & 52.1 & & 41.6 & $\sim 40$ & 52.74 & $35-40$ & $45.7-52.7$ \\
\hline
\end{tabular}

Table 4. Properties of different pyrolysis oils according to literature

\begin{tabular}{cc}
\hline Catalyst & CoMo [29][33][34][35][36], NiMo [34][35][36], others [37][38] \\
\hline Temperature $\left(^{\circ} \mathrm{C}\right)$ & $350-420$ \\
\hline Pressure (psig) & $1450-2900$ \\
\hline LHSV $\left(\mathrm{Hr}^{-1}\right)$ & $0.1-1.2$ \\
\hline Deoxygenation (wt\%) & $78-99.9$ \\
\hline Density (kg/l) & $0.9-1.03$ \\
\hline
\end{tabular}

Table 5. Single-stage pyrolysis oil hydroprocessing operating parameters

However, in the case of non-catalytic pyrolysis oils or for achieving better quality products, multiple-stage hydroprocessing can be employed for upgrading pyrolysis oils. Multiplestage hydroprocessing utilizes at least two different stages of hydroprocessing, which may 
include hydrotreating or hydrotreating and hydrocracking reactions. In the first stage the catalytic hydrotreatment reactor stabilizes the pyrolysis oil by mild hydrotreatment over $\mathrm{Co}^{-}$ Mo or NiMo hydrotreating catalyst [32;40-42]. The first stage product is then further processed in the second-stage hydrotreater, which operates at higher temperatures and lower space velocities than the first stage hydrotreater, employing also CoMo or NiMo catalysts within the reactor. The $2^{\text {nd }}$ stage product is separated into an organic-phase product, wastewater, and off-gas streams. In the literature [41], even a $3^{\text {rd }}$ stage hydroprocessing has been used for the heavy fraction (which boils above $350^{\circ} \mathrm{C}$ ) of the $2^{\text {nd }}$ stage product, where hydrocracking reactions take place for converting the heavy product molecules into gasoline and diesel blend components.

\begin{tabular}{|c|c|c|c|}
\hline Feed & $1^{\text {st }}$ stage & $2^{\text {nd }}$ stage & $3^{\text {rd }}$ stage \\
\hline Catalyst & $\begin{array}{c}\text { CoMo[32][40],NiMo[32][42], } \\
\text { others[39] }\end{array}$ & $\begin{array}{c}\text { CoMo[32][40]NiMo[32][42], } \\
\text { others [39] }\end{array}$ & CoMo[4141] \\
\hline Temperature $\left(\mathbf{C}^{\circ}\right)$ & $150-240$ & $225-370$ & $350-427$ \\
\hline Pressure (psig) & $1000-2000$ & 2015 & 1280 \\
\hline LHSV $\left(h r^{-1}\right)$ & $0.28-1$ & $0.05-0.14$ & \\
\hline Deoxygenation (wt\%) & & $60-98.6$ & \\
\hline
\end{tabular}

Table 6. Multiple-step pyrolysis oil hydroprocessing operating parameters

\subsection{Fischer-Tropsch wax upgrading}

Biofuels production via the Fischer-Tropsch technology is a conversion process of solid biomass into liquid fuels (Biomass-To-Liquid or BTL) as it is depicted in Figure 2. More specifically the solid biomass is gasified in the presence of air and the produced biogas rich in $\mathrm{CO}$ and $\mathrm{H}_{2}$ (synthesis gas), after being pretreated to remove coke residues and sulfur compounds, enters the Fischer-Tropsch reactor. The Fischer-Tropsch reactions allow the catalytic conversion of the synthesis gas into a mixture of paraffinic hydrocarbons consisting of light $\left(C_{1}-C_{4}\right)$, naphtha $\left(C_{5}-C_{11}\right)$, diesel $\left(C_{12}-C_{20}\right)$ and heavier hydrocarbons $\left(>C_{20}\right)$. Even though the Fischer-Tropsch reactions yields depend on the catalyst and operating parameters employed [43-45], the liquid product (naphtha, diesel and heavier hydrocarbons) yield is high ( 95\%). The produced synthetic naphtha and diesel fuels can be used similarly to their fossil counterparts. The heavier product however, which is called as Fischer-Tropsch wax, due to its waxy/paraffinic nature should get upgraded via catalytic hydrocracking to get converted to mid-distillate fuels (naphtha and diesel).

The conversion of Fischer-Tropsch wax into mainly diesel was studied in virtue of the European Project RENEW [46]. During this project Fischer-Tropsch wax with high paraffinic content of $\mathrm{C}_{20}-\mathrm{C}_{45}$ was converted into a total liquid product consisting of naphtha, kerosene and diesel fractions via catalytic hydrocracking. However the total liquid product content of diesel molecules was the highest and the diesel fraction was further separated and character- 
ized having density of $0.78 \mathrm{gr} / \mathrm{ml}$ and cetane index of 76 [47]. The schematic of the BTL process with actual images of the feedstock, Fischer-Tropsch wax and synthetic diesel are given in Figure 8.
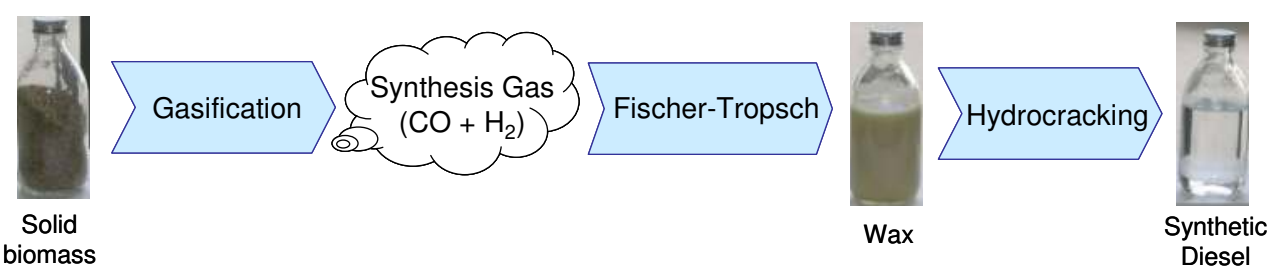

Figure 8. Biomass-to-Liquid production of synthetic diesel

\subsection{Micro-algal oil conversion to biofuels}

The rapid development of the biofuels production technologies from different biomass types has given rise to the biomass and food markets as it was aforementioned. Besides the use of residual biomass, research and in particular biotechnology has moved forward into seeking alternative biomass production technologies that will offer higher yields per hectare as well as lipids and carbohydrates, which are not part of the human and animal food-chain, avoiding competition between food/feed and energy crops. Targeted research efforts have offered a promising solution by the selection of unicellular microorganisms for the production of biofuels [48][49]. Micro-algae are photosynthetic microorganisms that can produce lipids, proteins and carbohydrates in large amounts over short periods of time.

Micro-algae are currently considered a prominent source of fatty acids, which offers large yields per hectare with various fatty acid foot-prints from each strain. In fact, there are certain strains that offer fatty acids of increased saturation (small content of unsaturated fatty acids) and of smaller carbon-chain length such as Dunaliellasalina, Chlorella minutissima, Spirulina maxima, Synechococcus sp.[50] etc. Another advantage of algal oils is that their fatty acid content can be directed to small carbon-chain molecules either genetically or by manipulating the aquaculture conditions such as light source and intensity [51], nitrogen starvation period [52], nutrients and $\mathrm{CO}_{2}$ feeding profiles [53].

Micro-algae and their products formulated the so called $3^{\text {rd }}$ generation biofuels, as they incorporate various characteristics, which render them superior over other biofuels and biomass types. Micro-algae can also be produced in sea water [54] or even waste water, while they are biodegradable and relatively harmless during an eventual spill. Furthermore, their yield per hectare can reach 3785-5678lit, which is 20-700 higher over the conventional energy crops yield (soy, rape and palm). The lipids contained in most micro-algal oils have a similar synthesis with that of soy-bean oil, while they also contain some poly-saturated fatty acids with four double bonds. As a result catalytic hydrotreating of micro-algal oil is the most promising technology for converting it into biofuels. 


\subsection{Co-hydroprocessing}

The effectiveness of catalytic hydroprocessing was also explored for co-processing of lipid feedstocks with petroleum fractions as catalytic hydroprocessing units are available in almost all refineries. The first co-processing study involved experiments of catalytic hydrotreating of sunflower oil mixtures with heavy petroleum fractions aiming to produce high quality diesel [55]. The experiments were conducted in a continuous fixed-bed reactor over a wide range of temperatures $300-450^{\circ} \mathrm{C}$ employing a typical $\mathrm{NiMo} / \mathrm{Al}_{2} \mathrm{O}_{3}$ hydrotreating catalyst. The study was focused on the hydrogenation of double $\mathrm{C}-\mathrm{C}$ bonds and the subsequent paraffin formation via the three different reactions routes: decarbonylation, decarboxylation and deoxygenation. Furthermore the large carbon-chain paraffins can also undergo isomerization and cracking leading to the formation of smaller paraffins. This study concluded that the selectivity of products on decarboxylation and decarbonylation is increasing as the temperature and vegetable oil content in the feedstock increase [55].

In a similar study catalytic hydrocracking over sunflower oil and heavy vacuum gas oil mixtures was investigated [56]. The experiments were conducted in a continuous-flow hydroprocessing pilot-plant over a range of temperatures $\left(350-390^{\circ}\right)$ and pressures (70-140bar). Three different hydrocracking catalysts were compared under the same conditions and four different feedstocks were employed, incorporating for $10 \%$ and $30 \% \mathrm{v} / \mathrm{v}$ of lipid bio-based feedstock and considering non-pretreated and pretreated sunflower oil as a bio-based feedstock. The results indicated that a prior mild hydrogenation step of sunflower oil is necessary before hydrocracking. Furthermore, conversion was increased with increasing sunflower oil ratio in the feedstock and increasing temperature, while the later decreased diesel selectivity.

The effect of the process parameters and the vegetable oil content of the feedstocks on the yield, physical properties, chemical properties and application properties during co-hydrotreating of sunflower oil and gas-oil mixtures utilizing a typical $\mathrm{NiMo} / \mathrm{Al}_{2} \mathrm{O}_{3}$ hydrotreating catalyst was also studied [57]. The experimental results of this study indicated that catalytic co-hydrogenation of gas oil containing sunflower oil in different percentages allowed both vegetable oil conversion reactions (saturation, deoxygenation) and the gas oil quality improvement reactions (hetero atom removal, aromatic reduction). The optimal operating conditions $\left(360-380^{\circ} \mathrm{C}, \mathrm{P}=80 \mathrm{bar}, \mathrm{LHSV}=1.0 \mathrm{~h}^{-1}, \mathrm{H}_{2} / \mathrm{oil}=600 \mathrm{Nm}^{3} / \mathrm{m}^{3}\right.$ and $15 \%$ sunflower oil content of feed) resulted in a final diesel product with favorable properties (e.g. less than $10 \mathrm{wppm}$ sulfur, $\sim 20 \%$ aromatics) but poor cold flow properties $\left(\mathrm{CFPP}=3^{\circ} \mathrm{C}\right)$. The study also indicated that for sunflower content in the feedstock higher than $15 \%$ reduced the desulfurization efficiency. Furthermore, the authors also concluded that the presence of sunflower oil in the feedstock has augmented the normal and iso-paraffins content of the final product and as a result has increased the cetane number but degraded the cold flow properties, indicating that an isomerization step is required as an additional step.

The issue of catalyst development suitable for co-hydrotreating and co-hydrocracking of gas-oil and vegetable oil mixtures was recently addressed [10], as there are no commercial hydroprocessing catalysts available for lipid feedstocks. New sulfided $\mathrm{Ni}-\mathrm{W} / \mathrm{SiO}_{2}-\mathrm{Al}_{2} \mathrm{O}_{3}$ and sulfided $\mathrm{Ni}-\mathrm{Mo} / \mathrm{Al}_{2} \mathrm{O}_{3}$ catalysts were tested for hydrocracking and hydrotreating of gas- 
oil and vegetable oil mixtures respectively. The results indicated that the hydrocracking catalyst was more selective for the kerosene hydrocarbons $\left(140-250^{\circ} \mathrm{C}\right)$, while the less acidic hydrotreating catalyst was more selective for the diesel hydrocarbons $\left(250-380^{\circ} \mathrm{C}\right)$. The study additionally showed that the deoxygenation reactions are more favored over the hydrotreating catalyst, while the decarboxylation and decarbonylation reactions are favored over the hydrocracking catalyst.

\section{Demo and industrial applications}

As catalytic hydrotreating of liquid biomass has given promising results, the industrial world has given enough confidence to apply it in pilot and industrial scale. The NesteOil Corporation has developed the NExBTL technology for converting vegetable oil (primarily palm oil) into a renewable diesel also known as "green" diesel (Figure 9). Based on this technology the first catalytic hydrotreatment of vegetable oils unit was constructed in Finland in 2007, within the existing Poorvo refinery of NesteOil, with a capacity of $170 \mathrm{kton} / \mathrm{hr}$. The primary feedstock is palm oil, while it can also process rapeseed oil and even waste cooking oil. The same company has constructed a second unit within the same refinery while it has also planned to construct two new units, one in Singapore and one in Rotterdam, with the capacity of $800 \mathrm{kton} / \mathrm{yr}$ each.

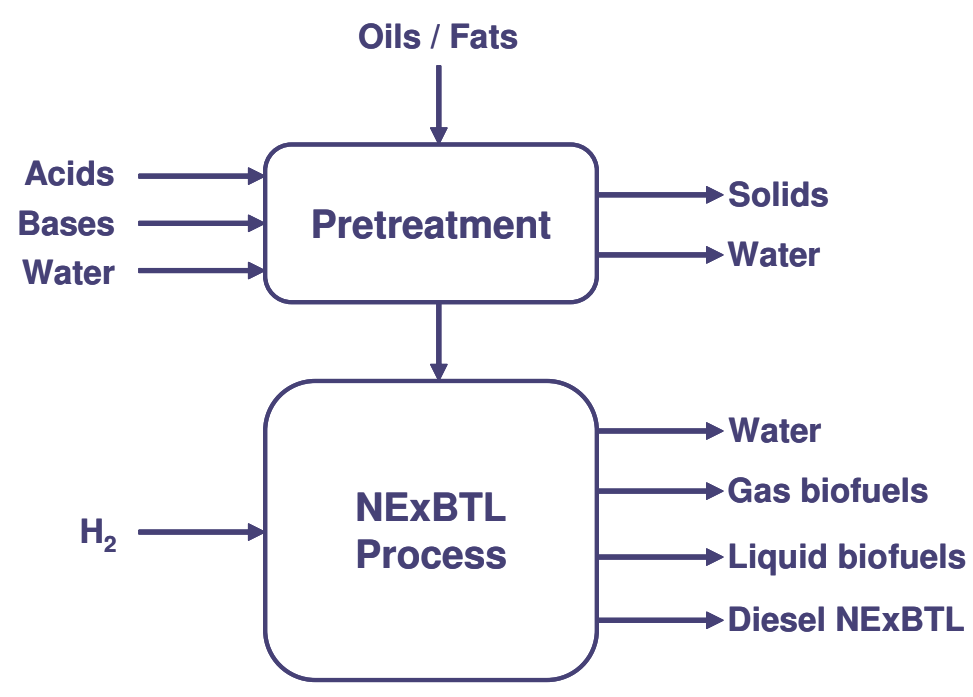

Figure 9. NExBTL catalytic hydrotreating of oils/fats technology for biodiesel production [58]

The catalytic hydrotreatment technology of $100 \%$ waste cooking oil for biodiesel production was developed in the Centre for Research and Technology Hellas (CERTH) in Thessaloniki, Greece [21-24] and later demonstrated via the BIOFUELS-2G project [59], which was co- 
funded by the European Program LIFE". In this project WCO was collected from associated restaurants and the produced $2^{\text {nd }}$ generation bio-diesel, to be called "white diesel" was employed. For the demonstration of the new technology, 2 tons of "white diesel' were produced via catalytic hydrotreatment of WCO based on the large-scale pilot units available in CERTH. The production process simplified diagram is given in Figure 10. The new fuel will be applied to a garbage truck in a 50-50 mixture with conventional diesel in August 2012, aiming to promote the new technology as it exhibits overall yields exceeding $92 \% \mathrm{v} / \mathrm{v}$.

In the USA the Dynamic Fuels company [60] has constructed in Baton Rouge a catalytic hydrotreating unit dedicated to oils and animal fats with 285 Mlit capacity. The unit employs the Syntroleum technology based on Fischer-Tropsch for the production of synthetic $2^{\text {nd }}$ generation Biodiesel while it also produces bio-naphtha and bio-LPG. The Bio-Synfining technology of Syntroleum converts the triglycerides of fats and oils into n- and iso-paraffins via catalytic hydrogenation, thermal cracking and isomerization as it is applied in the FischerTropsch wax upgrading to renewable diesel (R-2) and renewable jet (R-8) fuel.

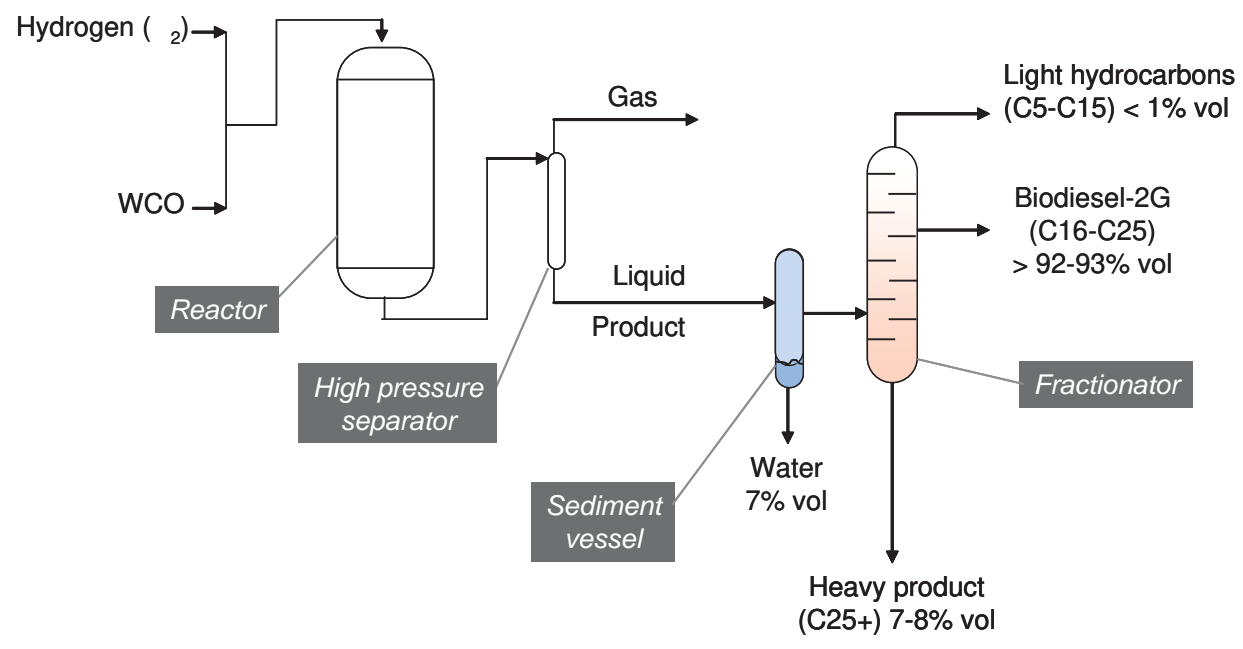

Figure 10. Pilot-scale demo application of WCO catalytic hydrotreatment during the BIOFUELS-2G project [59] 


\section{Future perspectives}

Catalytic hydrotreating of liquid biomass is continuously gaining ground as the most effective technology for liquid biomass conversion to both ground- and air-transportation fuels. The UOP company of Honeywell, via the technology it has developed for catalytic hydrotreating of liquid biomass (Figure 11), has announced imminent collaboration with oil and airline companies such as Petrochina, Air China and Boeing for the demonstration of the sustainable air-transport in China. This initiative will lead a strategic collaboration between the National Energy Agency of china with the Commerce and Development Agency of USA leading to the development of the new biofuels market in China.

\section{Selective Product}

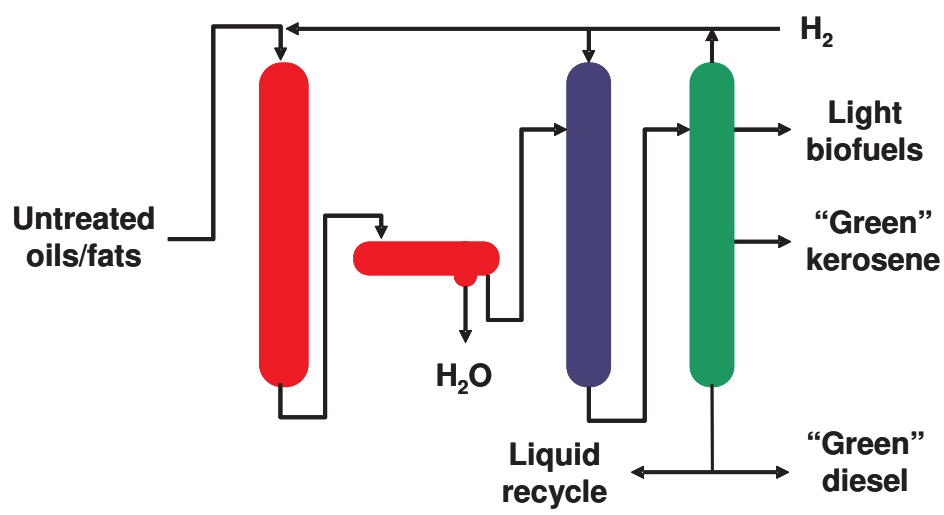

Figure 11. Vegetable oil and animal fats conversion technology to renewable fuels of UOP [61]

In the EU airline companies collaborate with universities, research centers and biofuels companies in order to confront their extensive contribution to $\mathrm{CO}_{2}$ emissions. Since 2008 most airline companies promote the use of biofuels in selected flights as shown in Table 7 [62]. As it is obvious most pilot flights have taken place with Hydrotreated Renewable Jet (HRJ), which is kerosene/jet produced via catalytic hydrotreatment of liquid biomass. Moreover, Lufthansa has also completed a 6-month exploration program of employing HRJ in a 50/50 mixture with fossil kerosene in one of the 4 cylinders of a plane employed for the flight between Hamburg-Frankfurt-Hamburg with excellent results [63].

Besides the future applications for air-transportation, the automotive industry is also exhibiting increased interest for the broad use of biofuels resulting from catalytic hydrotreatment of liquid biomass. In fact these paraffinic biofuels can be employed in higher than $7 \% \mathrm{v} / \mathrm{v}$ blending ratio (which is the maximum limit for FAME) as they exhibit high cetane number and have significant oxidation stability [64] 


\begin{tabular}{|c|c|c|c|c|}
\hline Airline & Aircraft & Partners & $\begin{array}{c}\text { Biofuel } \\
\text { (lipid sources) }\end{array}$ & Blend* \\
\hline Virgin Atlantic & B747-400 & Boeing, GE Aviation & $\begin{array}{c}\text { FAME } \\
\text { (coconut \& palm) }\end{array}$ & $20 \%$ \\
\hline Air New Zealand & B747-400 & Boeing, Rolls-Royce & $\begin{array}{c}\text { HRJ } \\
\text { (Jatropha) }\end{array}$ & $50 \%$ \\
\hline $\begin{array}{l}\text { Contintental } \\
\text { Airlines }\end{array}$ & B737-800 & $\begin{array}{c}\text { Boeing, GE Aviation, CFM, } \\
\text { Honeywell UOP }\end{array}$ & $\begin{array}{c}\text { HRJ } \\
\text { (Jatropha\&algea) }\end{array}$ & $50 \%$ \\
\hline$J A L$ & B747-300 & $\begin{array}{c}\text { Boeing, Pratt\&Whitney, } \\
\text { Honeywell UOP }\end{array}$ & $\begin{array}{c}\text { HRJ } \\
\text { (Camelina, Jatropha\& algae) }\end{array}$ & $50 \%$ \\
\hline KLM & B747-400 & GE, Honeywell UOP & $\begin{array}{c}\text { HRJ } \\
\text { (Camelina) }\end{array}$ & $50 \%$ \\
\hline TAM & A320 & Airbus, CFM & $\begin{array}{c}\text { HRJ } \\
\text { (Jatropha) }\end{array}$ & $50 \%$ \\
\hline
\end{tabular}

Table 7. Pilot flights with biofuels [62]

The highest interest is exhibited by oil companies around the catalytic hydrotreatment of liquid biomass technology for the production of biofuels and particularly to its application to oil from micro-algae. ExxonMobil has invested 600M\$ in the Synthetic Genomics company of the pioneer scientist Craig Ventner aiming to research of converting micro-algae to biofuels with minimal cost. BP has also invested 10M\$ for collaboration with Martek for the production of biofuels from micro-algae for air-, train-, ground- and marine transportation applications.

\section{Conclusion}

Catalytic hydrotreatment of liquid biomass is the only proven technology that can overcome its limitations as a feedstock for fuel production (low $\mathrm{H} / \mathrm{C}$ ratio, high oxygen and water content). Even though it has recently started to be investigated as an alternative technology for biofuels production, it fastly gains ground due to the encouraging experimental results and successful pilot/demo and industrial applications. Catalytic hydrotreatment of liquid biomass leads to a wide range of new alterative fuels including bio-naphtha, bio-jet and biodiesel, are paraffinic in nature and as a result exhibiting high heating values, increased oxidation stability and negligible acidity and corrosivity. As a result it is not over-optimistic to claim that this technology will broaden the biofuels market into scales capable to actually mitigate the climate change problems. 


\section{Acknowledgements}

The author would like to thank Ms Iva Simcic and InTech Europe for enabling her to publish this book chapter, while she is grateful to Mr Athanasios Dimitriadis who provided support, offered comments, proofreading and design. Finally she would like to express her appreciation for the financial support provided by the EU project BIOFUELS-2G which is co-financed by the European Program LIFE+.

\section{Author details}

Stella Bezergianni*

Address all correspondence to: sbezerg@cperi.certh.gr

Chemical Processes \& Energy Resources Institute (CPERI), Centre for Research \& Technology Hellas (CERTH), Thermi-Thessaloniki, Greece

\section{References}

[1] Meher LC, Vidya SD, Naik SN. Technical aspects of biodiesel production by transesterification-a review. Renewable and Sustainable Energy Reviews 2006;10 248-268.

[2] Naik SN., Goud VV, Rout OJ, Dalai AK. Production of first and second generation biofuels: A comprehensive review. Renewable and sustainable Energy Reviews 2010;14 578-597.

[3] Gary JH, Handwerk GE. Petroleum Refining, Technology and Economics, 4th ed. New York: Marcel Dekker; 2001.

[4] Furimsky E. Selection of catalysts and reactors for hydroprocessing. Applied Catalysis A: General 1998;171(2) 177-206.

[5] Birchem T. Latest Improvements in ACETM Catalysts Technology for ULSD Production \& Deep Cetane Increase. 5th ERTC Annual Meeting: conference proceedings, November 2010, Istanbul, Turkey.

[6] Donnis B, Egeberg RG, Blom P, Knudsen KG. Hydroprocessing of bio-oils and oxygenates to hydrocarbons. Understanding the reaction routes. Top. Catal. 2009; 52 229-240.

[7] Boda L, Onyestyák G, Solt H, Lónyi F, Valyon J, Thernesz A. Catalytic hydroconversion of tricaprylin and caprylic acid as model reactionfor biofuel production from triglycerides. Applied Catalysis A: General 2010;374 158-169. 
[8] Bezergianni S, Kalogianni A, Dimitriadis A, Catalyst Evaluation for Waste Cooking Oil Hydroprocessing, Fuel 2012;93 638-647.

[9] Funimsky E. Catalytic Hydrodeoxygenation. Applied Catalysis A: General 2000;199147-190.

[10] Tiwari R, Rana BS, Kumar R, Verma D, Kumar R, Joshi RK, Garg MO, Sinha AK. Hydrotreating and hydrocracking catalysts for processing of waste soya-oil and refinery-oil mixtures. Catalysis Communications 2011;12 559-562.

[11] Lavrenov AV, Bogdanets EN, Chumachenko YA, Likholobov VA. Catalytic processes for the production of hydrocarbon biofuels from oil and fatty raw materials: Contemporary approaches. Catalysis in Industry 2011;3(3) 250-259.

[12] Bulushev DA, Ross JRH. Catalysis for conversion of biomass to fuels via pyrolysis and gasification: A review. Catalysis Today 2011; 171(1) 1-13.

[13] Bezergianni S, Dimitriadis A, Kalogianni A., Pilavachi PA. Hydrotreating of waste cooking oil for biodiesel production. Part I: Effect of temperature on product yields and heteroatom removal. Bioresource Technology 2010;101 6651-6656.

[14] Tyson KS. Biodiesel Handling and Use Guidelines. National Renewable Energy Laboratory 2001, NREL/TP-580-30004

[15] Winayanuwattikun P, Kaewpiboon C, Piriyakananon K, Tantong S, Thakernkarnkit W, Chulalaksananukul W, Yongvanich T. Potential plant oil feedstock for lipase-catalyzed biodiesel production in Thailand. Biomass \& Bioenergy 2008;321279-1286.

[16] Da Rocha Filho GN, Brodzki D, Djega-Mariadassou G. Formation of alkanes alkylcykloalkanes and alkylbenzenes during the catalytic hydrocracking of vegetable oils. Fuel 1993;72 543-549.

[17] Gusmao J, Brodzki D, Djega-Mariadassou G, Frety R. Utilization of vegetable oils as an alternative source for diesel-type fuel: Hydrocracking on reduced Ni/ $\mathrm{SiO} 2$ and sulphided Ni-Mo/c-Al2O3. Cat Today 1989;5 533-544.

[18] Simacek P, Kubicka D, Sebor G, Pospisil M. Fuel properties of hydroprocessed rapeseed oil. Fuel 2010;89611-615.

[19] Simacek P, Kubicka D, Sebor G, Pospisil M. Hydroprocessed rapeseed oil as a source of hydrocarbon-based Biodiesel. Fuel 2009;88456-60.

[20] Bezergianni S, Kalogianni A. Hydrocracking of used cooking oil for biofuels production. Bioresource Technology 2009;100(17) 3927-3932.

[21] Bezergianni S, Dimitriadis A, Kalogianni A, Pilavachi PA. Hydrotreating of waste cooking oil for biodiesel production. Part I: Effect of temperature on product yields and heteroatom removal. Bioresource Technology 2010;101 6651-6656.

[22] Bezergianni S, Dimitriadis A, Kalogianni A, Knudsen KG. Toward Hydrotreating of Waste Cooking Oil for Biodiesel Production. Effect of Pressure, H2/Oil Ratio, and 
Liquid Hourly Space Velocity. Industrial Engineering Chemistry Research 2011;50(7) 3874-3879.

[23] Bezergianni S, Dimitriadis A, Sfetsas T, Kalogianni A. Hydrotreating of waste cooking oil for biodiesel production. Part II: Effect of temperature on hydrocarbon composition. Bioresource Technology 2010;101 7658-7660.

[24] Bezergianni S, Dimitriadis A, Voutetakis S. Catalytic Hydrotreating of Waste Cooking Oil for White Diesel Production. Proceedings of First International Congress on Catalysis for Biorefineries (CatBior), October 2-5,Torremolinos-Málaga, Spain; 2011

[25] Karonis D, Bezergianni S, Chilari D, Kelesidis E. Maximizing the yield of biodiesel from waste cooking oil hydroprocessing by cut-point optimization. Proceedings Am. Chem. Soc., Div. Fuel Chem. 2010; 55(1)

[26] DynamotiveBioOil Information Booklet 2009, http://ingenieria.read.net/blog/PIB-BioOil.pdf (last visited August 6, 2012)

[27] Venderbosch RH, Ardiyanti AR, Wildschut J, Oasmaa A, Heeres HJ. Stabilization of biomass-derived pyrolysis oils. J Chem.Technol.Bioetchnol. 2010; 85 674-686.

[28] Wildschut J, Mahfud FH, Venderbosch RH, Heeres HJ. Hydrotreatment of fast pyrolysis Oil Using Heterogeneous Noble-Metal Catalysts. Ind. Eng. Chem. Res. 2009;48 10324-10334.

[29] Wildschut J. Pyrolysis Oil Upgrading to Transportation Fuels by Catalytic Hydrotreatment. PhD Thesis. Rijksuniversiteit Groningen; 2009.

[30] Baldauf W, Balfanz U, Rupp M. Upgrading of Flash Pyrolysis Oil and Utilization in Refineries. Biomass and Bioenergy 1994;7(1-6) 237-244.

[31] Czernik S, Bridgwater AV. Overview of Applications of Biomass Fast Pyrolysis Oil. Energy\& Fuels 2004;18 590-598.

[32] Elliott DC, Neuenschwander GG. Liquid fuels by low severity hydrotreatment of biocrude. Developments in Thermochemical Biomass Conversion, Vol. 1, pp. 611-621, A. V. Bridgwater and D. G. B. Boocock, eds., Blackie Academic \& Professional, London: 1996

[33] Baker EG, Elliott DC. Catalytic Hydrotreating of Biomass-Derived Oils. Pacific Northwest Laboratory 1988.

[34] BorjeGevert S, Anderson PV, Sandqvist SP. Hydroprocessing of directly liquefied biomass with large-pore catalysts. Energy \& Fuels 1990;4 78-81.

[35] Elliott DC, Baker EG. Upgrading Biomass Liquefaction Products through hydrodeoxygenation. Biotechnol.Bioeng.Symp. 1984, suppl. 14, 159.

[36] Samolada MC, Baldauf W, Vasalos IA. Production of a Bio-Gasoline by Ugrading Biomass Flash Pyrolysis Liquids via Hydrogen Processing and Catalytic Cracking. Fuel $1998 ; 771667$. 
[37] de Miguel Mercader F, Groeneveld MJ, Kersten SRA, Way NWY, Schaverien CJ, Hogendoorn JA. Production of advanced biofuels: Co-processing of upgraded pyrolysis oil instandard refinery units. Applied Catalysis B: Environmental 2010;96 57-66.

[38] Oasmaa A, Kuoppala E, Ardiyanti A, Venderbosch RH, Heeres HJ. Characterization of Hydrotreated Fast Pyrolysis Liquids. Energy Fuels 2010;24 5264-5272.

[39] Venderbosch RH, Heeres HJ. Pyrolysis Oil Stabilisation by Catalytic Hydrotreatment. Biofuel's Engineering Process Technology.

[40] Jones SB, Holladay JE, Valkenburg C, Stevens DJ, Walton C, Kinchin C, Elliott DC, Czernik S. Production of Gasoline and Diesel from Biomass via Fast Pyrolysis, Hydrotreating and Hydrocracking: A Design Case. Prepared for the U.S. Department of Energyunder Contract DE-AC05-76RL01830. February 2009.

[41] Pindoria RV, Megaritis A, Herod AA, Kandiyoti R. A two-stage fixed-bed reactor for direct hydrotreatment of volatiles from the hydropyrolysis of biomass: effect of catalyst temperature, pressure and catalyst ageing timeon product characteristics. Fuel 1998;77(15) 1715-1726.

[42] Conti L, Scano G, Boufala J, Mascia S. Experiments of Bio-oil Hydrotreating in a Continuous Bench-Scale Plant. In: Bridgwater, A.V.; Hogan, E.N., editors. Bio-Oil Production and Utilization. CPL Press, Newbury Berks, 1996, 198

[43] Sharma RK, Bakhshi NN. Catalytic Upgrading of Pyrolysis Oil. Energy \& Fuels 1993;7 306-314.

[44] Subiranas M, Schaub A. Combining Fischer-Tropsch (FT) and hydrocarbon reactions under FT reaction conditions - Catalyst and reactor studies with $\mathrm{Co}$ or Fe and $\mathrm{Pt} /$ ZSM-5, International Journal of Chemical Reactor Engineering 2007; 5(A78).

[45] Rosyadi E, Priyanto U, Suprapto, Roesyadi A, Nurunnabi M, Hanaoka T, Miyazawa T, Sakanishi K, Biofuel production by hydrocracking of biomass FT wax over NiMo/ Al2O3-SiO2 catalyst, Journal of the Japan Institute of Energy 2011;90(12) 1171-1176.

[46] www.renew-fuel.com (accessed 8 August 2012)

[47] Lappas AA, Voutetakis SS, Drakaki N, Papapetrou M., Vasalos IA. Production of Transportation Biofuels through Mild-Hydrocracking and catalytic cracking of waxes produced from Biomass to Liquids (BTL) Process. Proceedings of the 14thEuropean Biomass Conference, Paris France; 2005

[48] Posten C, Schaub G. Microalgae and terrestrial biomass as source for fuels - a process view. J.Biotechnol. 2009;142 64-69.

[49] Schenk PM, Thomas-Hall SR, Stephens E, Marx UC, Mussgnug JH, Posten C, Kruse O, Hankamer B. Second Generation Biofuels: High-Efficiency Microalgaefor Biodiesel Production. Bioenerg Res 2008;120-43

[50] Patil V, Källqvist T, Olsen E, Vogt G, Gislerød HR. Fatty acid composition of 12 microalgae for possible usein aquaculture feed. Aquaculture International 2007;151-9. 
[51] Kachroo D, Jolly SMS, Ramamurthy V. Modulation of unsaturated fatty acids content in algae Spirulinaplatensis and Chlorella minutissima in response to herbicide SAN 9785. Electronic Journal of Biotechnology 2006;9(4)386-390.

[52] Chen M, Tang H, Ma H, Holland TC, Ng KYS, Salley SO. Effect of nutrients on growth and lipid accumulation in the green algae Dunaliellatertiolecta, Bioresource Technology 2011;1021649-1655.

[53] Yoo C, Jun SY, Lee JY, Ahn CY, Oh HM. Selection of Microalgae for Lipid Production under High Levels Carbon Dioxide. Bioresource Technology 2010;101 S71-S74.

[54] Popovich CA, Damiani C, Constenla D, Martínez AM, Freije H, GiovanardiM, Pancaldi S, Leonardi PI. Neochlorisoleoabundans grown in enriched natural seawater for Biodiesel feedstock: Evaluation of its growth and biochemical composition. Bioresource Technology 2012;114 287-293.

[55] Huber GW, O'Connor P, Corma A. Processing biomass in conventional oil refineries: production of high quality diesel by hydrotreating vegetable oils in heavy vacuum oil mixtures. Applied Catalysis A: General 2007;329120-129.

[56] Bezergianni S, Kalogianni A, Vasalos IA. Hydrocracking of vacuum gas oil-vegetable oil mixtures for biofuels production. Bioresource Technology 2009;1003036-3042.

[57] Tóth C, Baladincz P, Kovács S, Hancsók J. Producing Diesel Fuel by Co-Hydrogenation of Vegetable Oil with Gas Oil. Chemical Engineering Transactions 2010;21 1219-1224.

[58] Neste Oil Corporation.NexBTL diesel. http://www.nesteoil.com/default.asp? path=1,41,11991,12243,12335 (accessed 15 July 2012).

[59] BIOFUELS-2G project. http://www.biofuels2g.gr(accessed 20 July 2012).

[60] Dynamic Fuels. http://www.dynamicfuelsllc.com/ (accessed 18 July 2012).

[61] Honneywell's UOP. http://www.uop.com (accessed 5 July 2012).

[62] Steele P. Powering the Future of Flight. In Proceedings of the World Biofuels Markets 2011, March 22-24, Rotterdam, The Netherlands.

[63] Buse J. Commercialization of Aviation Biofuels. In Proceedings of the World Biofuels Markets 2011, March 22-24, Rotterdam, The Netherlands.

[64] Lahaussois D, Desaeger M. 10\% Renewable Energy in transport by 2020: a car manufacturer's perspective. In Proceedings of the World Biofuels Markets 2011, March 22-24, Rotterdam, The Netherlands. 